\title{
Scorpion fauna of the island of Fernando de Noronha, Brazil: first record of Tityus stigmurus (Thorell 1877) (Arachnida, Buthidae)
}

\author{
Gilson Carlos Conceição Freitas ${ }^{1} \&$ Simão Dias Vasconcelos ${ }^{1,2}$ \\ ${ }^{1}$ Laboratório de Invertebrados Terrestres, Departamento de Zoologia, Centro de Ciências Biológicas, \\ Universidade Federal de Pernambuco - UFPE \\ Av.Prof. Moraes Rego, s/n, CEP 50670-420, Recife, PE, Brazil,e-mail: gilson_freitas@hotmail.com \\ ${ }^{2}$ Autor para correspondência: Dr. Simão Dias Vasconcelos, e-mail: simao@ufpe.br
}

FREITAS, G.C.C. \& VASCONCELOS, S.D. 2008. Scorpion fauna of the island of Fernando de Noronha, Brazil: first record of Tityus stigmurus (Thorell, 1877) (Arachnida, Buthidae). Biota Neotrop. 8(2): http:// www.biotaneotropica.org.br/v8n2/en/abstract?short-communication+bn00508022008.

Abstract: A survey of the scorpion fauna of the Island of Fernando de Noronha, Pernambuco (Brazil), was carried out in October 2005. Methods included active collecting and pitfall traps in several areas of the island under different degrees of human-caused alteration. Forty four scorpions, belonging to two species were collected: Isometrus maculatus (DeGeer, 1778), previously listed for the Island, and Tityus stigmurus (Thorell, 1877), here recorded for the first time. This species was probably introduced via cargo shipments from the continent and offers risk to the local population due to the gravity of the accidents.

Keywords: faunistics, Chelicerata, scorpions.

FREITAS, G.C.C. \& VASCONCELOS, S.D. 2008. Escorpiofauna da ilha de Fernando de Noronha, Brasil: primeiro registro de Tityus stigmurus (Thorell, 1877) (Arachnida, Buthidae). Biota Neotrop. 8(2): http:// www.biotaneotropica.org.br/v8n2/pt/abstract?short-communication+bn00508022008.

Resumo: Foi conduzido um levantamento sobre a escorpiofauna de Fernando de Noronha, Pernambuco (Brasil), em outubro de 2005. Os métodos incluíram coleta ativa e armadilhas de queda em várias regiões da ilha, sob diferentes graus de alteração antrópica. Foram coletados 44 escorpiões de duas espécies: Isometrus maculatus (DeGeer, 1778), previamente listada para a ilha, e Tityus stigmurus (Thorell, 1877), registrada pela primeira vez. Trata-se de uma espécie provavelmente introduzida através do tráfego de material do continente, e que oferece risco à população local, devido à gravidade dos acidentes.

Palavras-chave: faunística, Chelicerata, escorpiões. 


\section{Introduction}

With approximately 1,500 described species, scorpions (Order Scorpiones) inhabit a wide range of terrestrial micro-habitats and are present in all continents, except Antarctica (Sissom 1990, Lourenço \& Eickstedt 2003). Eighty six species are recorded from Brazil, belonging to four families: Bothriuridae, Buthidae, Chactidae and Liochelidae (Lourenço \& Eickstedt 2003). In Northeastern Brazil, Tityus stigmurus (Thorell 1877) (Buthidae) is of medical importance, especially in urban areas of Bahia (Lira-da-Silva et al. 2000) and Pernambuco, where four deaths that occurred from 1999 to 2004 were attributed to the species (Sinitox 2007).

Field studies on the diversity of scorpions are particularly important in areas where human impact might have altered the original fauna by driving native species to extinction or by favoring the establishment of exotic ones. This study aimed to survey the scorpion species of Fernando de Noronha, because there is virtually no data on arachnids from the island and because the increase in the human and cargo flow from the continent may contribute to the introduction of new species, including those of medical importance. One of the World's Natural Heritages, according to Unesco, the archipelago is intensely visited by tourists and has been strongly modified by human activity.

\section{Material and Methods}

The Fernando de Noronha archipelago ( $3^{\circ} 50^{\prime} \mathrm{S}$ and $32^{\circ} 15^{\prime} \mathrm{W}$ ), with a total area of $18.4 \mathrm{~km}^{2}$, is situated $345 \mathrm{~km}$ northeast of the nearest Brazilian mainland, Cabo São Roque (RN) (Figure 1). In addition to the Island of Fernando de Noronha itself, with $16.9 \mathrm{~km}^{2}$, there are several smaller islets that comprise this volcanic archipelago (Teixeira et al. 2003). The climate is tropical, with two well-defined seasons: dry (August to January) and rainy (February to July). The temperature ranges from 23.5 to $31.5^{\circ} \mathrm{C}$, with an annual average of $27.0^{\circ} \mathrm{C}$ (Ibama 2007). Soil is low in depth and permeability, which does not allow much water retention. Native vegetation, characterized as a seasonal deciduous forest, is poor and primarily represented by bushes and herbs, with several introduced species (Teixeira et al. 2003). The island suffers from water shortage, as there are no permanent freshwater reservoirs.

The collection expeditions took place in October 2005 (dry season). Two methodologies were used: diurnal active collection and pitfall trapping. Active collection was conducted in places indi- cated by local inhabitants, to concentrate the efforts in areas where scorpion presence had been reported. Places such as residences, crops, storehouses and abandoned edifications were inspected daily. Scorpions were collected with forceps on the ground, under bark, stones, construction debris and in residences. Widespread and/or more exhaustive collection was not used due to legal restrictions.

Pitfall traps $(\mathrm{N}=190)$ made out of $500 \mathrm{~mL}$ plastic cups $(7 \mathrm{~cm}$ diameter), were buried at ground level and filled with $200 \mathrm{~mL}$ of $70 \%$ alcohol. They were scattered throughout several points in the island, including preserved areas, inaccessible for tourists, beaches, mangroves, open fields and urban areas, strongly modified by human presence. Collection lasted 15 days and involved three researchers, with an effort of two hours/day. Captured animals were conserved in $70 \%$ alcohol. Identification was confirmed by comparison with specimens from the Arachnological Collection of the Instituto Bu$\operatorname{tantan}$ (IBSP), where they were further deposited.

\section{Results and Discussion}

Forty-four scorpions, belonging to two species: Isometrus maculatus (DeGeer 1778) (Buthidae) $(\hat{\delta}=5, q=10$, plus 27 juveniles) and T. stigmurus $(+=2)$ were captured, all of them in the dry season. Only two specimens (I. maculatus) were caught in pitfall traps.

Isometrus maculatus is a ubiquitous species from the Indomalayan region (Kovařík 2003) with Pantropical distribution, partly due to its propensity to be transported by humans (e.g., in ships) and to the ecological characteristics of opportunistic species (Lourenço 2002). Tityus stigmurus is recorded in all Northeastern states of Brazil, with the exception of Maranhão, and is occasionally found in Southern and Central Brazil, where it used to be more abundant in the past (Lourenço 2001, Lourenço \& Eickstedt 2003).

We report the first record of $T$. stigmurus in the archipelago, from where only I. maculatus was previously known (Lourenço 1982). It is also the first record of this species in a Brazilian oceanic island, which widens the biogeographical range of the species in $345 \mathrm{~km}$ to the east from the nearest Brazilian coast. This discovery is important due to the gravity of the accidents caused by this species and to its ecological plasticity as a typical opportunistic species (Lourenço 2001).

The lack of ecological planning for the occupation of the Island of Fernando de Noronha and the landscape alterations caused by the

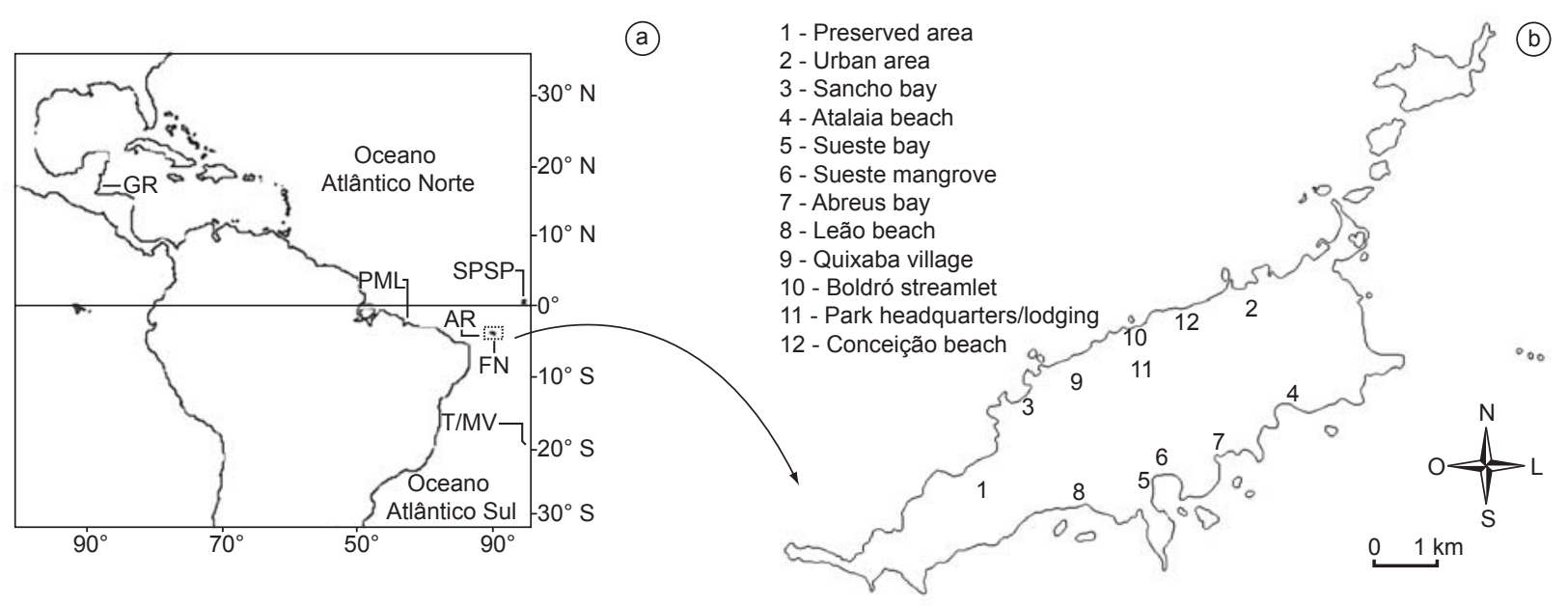

Figure 1. a) Location of the Fernando de Noronha (FN) archipelago, Brazil, and b) Location of collecting points in the Island of Fernando de Noronha. Figura 1. a) Localização do Arquipélago de Fernando de Noronha (FN), Brasil, e b) Localização dos pontos de coleta na Ilha de Fernando de Noronha. 
construction of a seaport, an airport and a dam resulted in radical extinction of the original fauna and flora (ca. 95\%) and the introduction of several species (Ibama 2007). The presence of T. stigmurus on the island corroborates the role of human and cargo transport in the movement of species to and from the island. This is supported by the collection of one specimen on construction material and the other in a medicine cargo destined to the local hospital. Both loads came from the continent, as the island is almost totally dependent of outside products.

Both species were found in inhabited areas, which indicate a tendency towards adaptation to anthropic environments. Furthermore, they reproduce quickly, possess a short life span and disperse easily (Lourenço \& Eickstedt 2003). Several testimonies of scorpion stings compiled during the survey among the local population suggest that T. stigmurus might be implicated. Considering that the specimens caught were large sized females, the possibility of establishment in the island is of concern, especially if parthenogenesis in this species is confirmed.

The low number of scorpion species found on the island is not surprising given the overall low animal diversity in the island (Ibama 2007). Therefore, a strong dependence on human mediated transport and some degree of ecological plasticity are requirements met by opportunistic species, such as I. maculatus and T. stigmurus. The history of disastrous introduction of animal species in the island - of which the "teju" Tupinambis teguixin (Reptilia: Squamata) is perhaps the most harmful example - calls the attention for rigorous inspection of cargo transport to and from the island, to reduce risks of establishment of exotic species - with all the medical and ecological risks associated.

\section{Acknowledgments}

We thank Antonio D. Brescovit for helpful comments on this manuscript, the Instituto Brasileiro do Meio Ambiente e dos Recursos Naturais Renováveis (Ibama, License \#57/2005) for the logistic support, and Facepe (Pernambuco State Government), Capes, CNPq (grant \#301776/2004-0), for financial support.

\section{References}

IBAMA - Instituto Brasileiro do Meio Ambiente e dos Recursos Naturais Renováveis. http://www.ibama.gov.br (accessed on 10/10/2007).

KOVAĽÍK, F. 2003. A review of the genus Isometrus Ehrenberg, 1828 (Scorpiones: Buthidae) with descriptions of four new species from Asia and Australia. Euscorpius 10: 1-19.

LIRA-DA-SILVA, R.M., AMORIM, A.M. \& BRAZIL, T.K. 2000. Envenenamento por Tityus stigmurus (Scorpiones; Buthidae) no Estado da Bahia. Rev. Soc. Bras. Med. Trop. 33(3): 289-245.

LOURENÇO, W.R. 1982. Presença do escorpião Isometrus maculatus (DeGeer, 1778) na Reserva Biológica de Atol das Rocas. Brasil Florestal 12(52): 61-62.

LOURENÇO, W.R. 2001. The Brazilian scorpion Tityus stigmurus (Chelicerata, Buthidae) and its complex of morphos. A new model is needed. Bigeographica 77(1): 21-34.

LOURENÇO, W.R. 2002. Scorpions of Brazil. Les Éditions de I'If, Paris.

LOURENÇO, W.R. \& EICKSTEDT V.R.D. 2003. Escorpiões de importância médica. In Animais Peçonhentos no Brasil: Biologia, Clínica e Terapêutica (J.L.C. Cardoso et al., eds.). Sarvier, São Paulo, p. 182-197.

SINITOX. http://www.fiocruz.br/sinitox/ (accessed on 20/02/2007).

SISSOM, W.D. 1990. Systematics, biogeography and paleontology. In The biology of scorpions (G.A. Polis, ed.). Stanford University Press, Palo Alto, p.64-160.

TEIXEIRA, W., CORDANI, U.G., MENOR, E.A., TEIXEIRA, M.G. \& LINSKER, R. 2003. Arquipélago Fernando de Noronha: o paraíso do vulcão. Terra Virgem, São Paulo. 